\title{
The Impact of the Lack of ICT Resources on Teaching and Learning in Selected South African Primary Schools
}

\author{
Paul Nwati Munje and Thuthukile Jita \\ University of the Free State, South Africa \\ https://orcid.org/0000-0002-7948-9704 \\ https://orcid.org/0000-0002-1173-5251
}

\begin{abstract}
The impact of Information and Communication Technology (ICT) on teaching and learning globally necessitates its integration in the classroom. Integration in individual school contexts, however, remains a challenge, despite ICT integration being a policy prerogative in many countries. This qualitative paper aims to understand how the lack of ICT resources affects the way learners learn and perform. Semi-structured interviews were utilized to gather data from six educators in three South African primary schools. The interviews were transcribed manually and coded. A thematic mode of analysis was used during the data analysis process. Findings show that, for multiple reasons, schools do not use ICT tools in teaching and learning, as expected, and, in some cases, underutilize existing resources, with implications for teaching and learning. We suggest that the South African Department of Basic Education (DBE) considers individual school contexts when allocating ICT resources, to ameliorate existing challenges. Reinforcing existing monitoring and evaluation mechanisms will facilitate the identification of contextual challenges and the provision of assistance where necessary. Most importantly, schools should be encouraged to form partnerships with communities to ensure the safety of ICT resources. These measures have the potential to ensure that all learners enjoy opportunities introduced in the classroom through the DBE's ICTintegration program, thus guaranteeing quality education for all.
\end{abstract}

Keywords: disadvantaged communities; ICT integration; information and communication technology; teaching and learning

\section{Introduction}

The dynamics associated with the integration of information and communication technology (ICT) in classrooms around the world have resulted in divergent views on how to approach this phenomenon from a school perspective. There needs to be a clear understanding of how well schools succeed in integrating ICT in teaching and learning. One of these approaches to 
ICT integration advocates consideration of the school context. This is because some of the challenges that schools encounter in their effort to integrate technology in teaching and learning are context-specific, thus needing contextfriendly solutions. Rabah (2015, p. 24) emphasized that "it would be inappropriate to view ICT-based education without taking into consideration the school's context, setting, and environment," as these factors have serious and varied implications.

In exploring ICT integration in teaching and learning in Hong Kong, Yuen, Law, and Wong (2003) identified possible contextual challenges. These include value systems; innovation processes in place; the nature of teacher commitment and support; and teacher professional development. Also, Karunaratne, Peiris, and Hansson (2018) noted that a lack of resources is a potential negative contextual factor hindering ICT usage in some classrooms. Khan (2020) contended that using ICT in teaching and learning has the potential to improve learner achievement, especially in areas with low socioeconomic status, with learner achievement more likely below expectations. This creates a need for empirical studies to provide a national picture of the impact the lack of ICT resources has on teaching and learning, especially in areas with low socioeconomic status. This paper thus focuses on exploring how the lack of ICT resources impacts on teaching and learning in selected South African primary schools.

\subsection{Research context}

To obtain a better diagnosis of the state of ICT integration in classrooms across the country, it is important to understand the "events, activities, contents, and interpersonal processes taking place in the context that ICT is used" (Lim, 2002, p. 411). The Department of Education (DBE) categorizes the schools selected for this study as quintile 1 (no-fee) schools. These schools receive similar government support and host learners from the same community. This classification is a result of the National Norms and Standards for School Funding (NNSSF) policy, aimed at ensuring equity and redressing imbalances of the apartheid era in all spheres, including education (DBE, 2011). It is important to note that the Department of Education in South Africa existed until 2009 when it was split into the Department of Higher Education and the Department of Basic Education. Owing to the challenges that work against endeavors to achieve equity, schools in disadvantaged communities continue to lag in terms of school resources, including ICT. Mirzajani, Mahmud, Ayub, and Wong (2016) argued that in such circumstances, teachers are likely to be discouraged to integrate ICT in the classroom. As a case in point, some of the selected schools for this study either did not have ICT resources for varied reasons or were underutilizing existing resources. This paper pursues the following questions:

- What is the relevance of ICT resources on teaching and learning in primary schools?

- What impact does the lack of ICT resources have on teaching and learning in primary schools? 


\subsection{ICT integration in South Africa: a retrospect}

For close to two decades, South Africa has consistently galvanized efforts and resources towards achieving a paperless classroom, to provide learners with better and limitless learning opportunities, including engaged learning environments. This is because ICT has the potential to contribute to improving learner abilities to learn across disciplines and fields. As such, South Africa's ICT mission is included in the country's National Development Plan 2030 (Mjwara, 2017). In 2003, the Department of Education (DoE), cognizant of ICT's advantages for learners, for the first time committed itself to ensure that every learner in South Africa has access to ICT resources and is technologically literate by 2013 (DoE, 2003, p. 17). This commitment provided the basis for multiple engagements to achieve ICT integration across South Africa.

The Gauteng Provincial education department, for example, endorsed and embraced the ICT-integration initiative with passion, aiming to make learning simpler and more enjoyable for all learners through the provision of ICT tools (Odendaal, 2017). This commitment was exhibited against the backdrop that introducing technology in the classroom has the potential to change the negativity associated with the South African education system, including the discouraging performance by learners in the Trends in International Mathematics and Science Study (TIMSS) (Rabana \& Martin, 2017). This is because technology in a Mathematics classroom, e.g., bears advantages. These include its ability to grab attention, motivate (Zakaria \& Khalid, 2016), and provide authentic learning environments, such as where learners can engage in web-based inquiry (Le Thi, 2020; Yang \& Baldwin, 2020). In the same vein, Denoon-Stevens and Ramaila (2018) argued that the availability of ICT facilities, especially in disadvantaged communities, has the potential to develop social capital and empower individuals and the community at large, a thought shared by Ismail, Jogezai, and Baloch (2020). However, attaining that potential seems elusive, considering that schools such as those included in this study are continuously deprived of ICT resources, considered by the Minister of Basic Education as further compromising the education of learners (Maromo, 2020; Mbuza, 2020).

The 2013-2025 e-Education strategy of the DBE is another milestone that serves as a roadmap for achieving the country's ICT-integration plan (DBE, 2014). The implementation strategy of this plan had specific roles and responsibilities for relevant stakeholders, including provincial education departments (DBE, 2014). In reporting on the progress of this plan, the DBE in February 2018 pointed out that it had successfully connected 16,102 schools nationally with basic ICT resources, of which 1,951 were in the Western Cape province (Parliament of the Republic of South Africa, 2018).

Figures provided by the DBE indicate that the integration plans are progressing well; and the Western Cape is ranked the fourth province in terms of South Africa's ICT penetration. Irrespective of the encouraging figures, the question that should be asked is whether the majority of primary school learners in socioeconomically disadvantaged communities in the Western Cape of South Africa are benefitting fully from this government initiative. Available ICT 
resources in the classroom are either non-utilized or underutilized, with negative implications for teaching and learning. The DBE admitted that its ICTintegration efforts nationally are poor due to a shortage of funds (Parliament of the Republic of South Africa, 2018). Garg, Shukla, and Kendall (2015) agreed that cost can potentially affect the implementation of any ICT-integration plan. This explains why nearly 11,858 primary schools lacked computer laboratories, and up to 9,313 had no Internet connectivity across South Africa by July 2018 (Parliament of the Republic of South Africa, 2018). These figures indicate that despite efforts made by the DBE to integrate technology in classrooms, many children are yet to benefit fully for various reasons. This justifies our decision to focus on understanding the impact that the lack of ICT resources has on teaching and learning.

Despite the desire to see that ICT emerges as a "game-changer" in the South African education system, the pace of integration in some school contexts is slower than expected. In an attempt to fast-track and monitor its ICT-implementation plan in schools across the country, the DBE introduced what it calls Operation Phakisa [phakisa means hurry up in Sesotho] (Kwet, 2017). Operation Phakisa is a philosophy that ensures speedy identification of existing challenges for the provision of relevant solutions to ameliorate the situation (Kwet, 2017). Regardless, ICT is yet to have a tangible effect in some under-resourced schools in various parts of the country (Chisango \& Lesame, 2017). For example, Pholotho and Mtsweni (2016) pointed out that poor service delivery was one of the reasons why some schools in the Limpopo province of South Africa were still to benefit adequately from the government's ICT-integration initiative. Using studies such as Pholotho and Mtsweni (2016) as a catalyst, this paper seeks to understand the impact that the lack of ICT resources has on teaching and learning in primary school classrooms.

\subsection{Challenges associated with ICT integration in South Africa}

Challenges experienced by some schools in the process of ICT integration have included intermittent Internet connectivity and the lack of appropriate administrative support (Wilson-Strydom, Thomson, \& Hodgkinson-Williams, 2005), with varying implications for the classroom. Besides, inadequate technical support to maintain ICT equipment remains a huge challenge in South African primary schools (Papaioannou \& Charalambous, 2011; Pholotho \& Mtsweni, 2016; Wilson-Strydom et al., 2005). These challenges are considered by Ismail et al. (2020) as common in developing countries. In this regard, Mirzajani et al. (2016) argued that challenges related to insufficient technical support in terms of ICT integration in the classroom are not unique to South African schools. In their view, these challenges are common but resolvable when schools and the administration work together closely to identify and resolve existing challenges and provide relevant pieces of advice. This approach has the potential to ensure stable Internet connectivity and to avoid underutilization of computer facilities (Pholotho \& Mtsweni, 2016), thus ensuring continuous usage of technological resources in classrooms. Unstable Internet connectivity is an ongoing challenge that extends beyond the boundaries of South Africa (Arrieta, 2020; Habibi, Razak, Yusop, Mukminin, \& Yaqin, 2020). 
Contextual challenges have the potential to dampen the zeal of educators to use ICT in teaching and learning (see Bingimlas, 2009), and to ultimately stifle the realization of the DBE's ICT-integration objectives countrywide. If these contextual realities are not addressed timeously, South Africa's ICT-integration agenda will remain a dream. Padayachee (2017) argued that, due to existing contextual challenges, ICT integration in some South African schools remains low and contributes to some educators questioning the usefulness of the Department's e-Education policy (DoE, 2004). Therefore, there is a need for the DBE to place more emphasis on regularly auditing the technological wellbeing of individual schools to ascertain their experiences regarding ICT integration. In doing so, the DBE can understand what kind of assistance to render to facilitate the implementation process. Without such measures, the good intentions of the DBE towards ICT integration in all schools would not materialize on time due to contextual realities that restrict the ability of educators to integrate ICT in classroom spaces. This paper focused on understanding the impact of the lack of ICT resources in teaching and learning in selected South African primary schools.

\section{Methods}

This qualitative paper reports on how the lack of ICT resources impacts on learners' ability to learn and perform. This case study (Yin, 2018) focused on three primary schools within South Africa, located in communities with low socioeconomic status. Data gathering involved six educators who responded to semi-structured interviews on ICT-related matters. Two Grade 7 educators were chosen from each school, using the purposeful sampling technique (Patton, 2005). Principals assisted in identifying the relevant educators to participate in the study since they knew which educators would be able to provide the required information. However, considering that principals are in a position of authority and prospective educator participants may have felt obligated to participate, an intention to participate form was supplied to the selected educators to indicate their willingness to participate voluntarily. This was done to ensure transparency (Aluwihare-Samaranayake, 2012) and to avoid abuse of power by the principals. Some of the selected educators had been teaching at the schools for up to ten years and therefore possessed a wealth of knowledge concerning the challenges faced by the schools, especially concerning ICT-related matters. They were also knowledgeable about the circumstances prevailing at school and how these affect learners' learning abilities. The participants were asked questions that required them to elaborate on the usefulness of ICT in teaching and learning, and the implications of the lack thereof. Participants, through interaction, demonstrated their awareness of how existing challenges affected learners' abilities to learn and perform as expected.

An audio recorder was used to record the interviews, with the permission of participants. Interviews lasted between 30 to 45 minutes. Although participants responded to semi-structured interviews, follow-up questions were asked for clarity purposes. The data were double-checked to ensure validity and reliability (Merriam, 2009). Manual coding was used because, throughout the research process, the researchers developed an understanding of the nature of the data, 
making transcription easier (Williams \& Moser, 2019). Also, emerging patterns and meanings could be easier identified (Joffe, 2012). After manual transcription and coding, data were merged and coded into major themes (Flick, 2018) using the thematic mode of analysis. The thematic mode of analysis was chosen because of its flexibility (Terry, Hayfield, Clarke, \& Braun, 2017). Additionally, its analysis process allows for the testing and reporting of coding reliability (Terry et al., 2017, p. 19). The themes emerging from the thematic analysis process include (1) the relevance of ICT in teaching and learning and (2) the impact that the lack of ICT resources has on teaching and learning.

The Western Cape Education Department permitted the study to be conducted in the province (reference number 20120222-0089). The authors ensured that participation was voluntary, with assistance from the principals. Participants signed written informed consent forms to make participation official, voluntary, and to protect them from harm (Merriam \& Grenier, 2019). For confidentiality purposes, the participating schools are codenamed A, B, and C. The educator participants are designated as A1 and A2 for School A, B1 and B2 for School B, and $\mathrm{C} 1$ and $\mathrm{C} 2$ for School C.

\section{Delimitation of the study}

The study focused on the impact that the lack of ICT resources has on teaching and learning in three primary schools within a community of low-socioeconomic status in South Africa. The study targeted Grade 7 classrooms in each of the schools. Grade 7 was chosen because it is an exit level in primary schools in the South African education system, where learners are expected to possess certain competencies before proceeding to high school. Since the study was limited to Grade 7, two Grade 7 educators from each of the three schools participated in the study. Participants were identified with the assistance of the principals of each school to possess a wealth of knowledge regarding the challenges faced by their respective schools, especially in the domain of technology usage in the classroom. Based on the limited sample of participating educators because the focus was on Grade 7 classrooms, conclusions made can apply only to the context under study and not to the whole of South Africa. Therefore, more studies of this nature using a large sample size are encouraged to produce more findings that can complement those emerging from this study. This will provide a holistic picture of ICT usage in South African primary school classrooms.

\section{Findings and discussion}

Undoubtedly, ICT is relevant in teaching and learning environments, the lack thereof thus impacting negatively on how learners learn and perform academically. However, the lack of or underutilization of ICT resources cannot be used as a measuring rod for learner academic performance. Nevertheless, its impact on learner motivation and increased aspirations to learn cannot be ignored (Denoon-Stevens \& Ramaila, 2018; Hilton, 2018; Jimenez, 2020; Santos, Ramos, Escola, \& Reis, 2019). Genlott and Grönlund (2016, p. 69) noted that "[w]hile technology in itself does not lead to improvement of student results, it may well be used to reinforce pedagogic factors that have been shown to have [a] positive impact". This is because, irrespective of the importance of ICT, its 
impact in individual schools is likely to vary for different reasons, including uniqueness in the kind of resources required to ensure learner academic performance. Still, this variable need does not in any way dispute the fact that learners' inability to access ICT resources in the selected schools has had negative implications for their educational aspirations and performance. Two main themes emerged from the findings: (1) the relevance of ICT in teaching and learning, and (2) the impact that the lack of ICT resources has on teaching and learning.

\subsection{The relevance of ICT in teaching and learning}

The participants agreed that ICT resources have the potential to change the way teaching and learning were taking place, how learners perceived education, learned, and performed. It emerged that, even in those schools without ICT resources, the relevant participants hypothetically appreciated its relevance in teaching and learning spaces. They particularly highlighted its potential to motivate learners and positively influence their performance (see DenoonStevens \& Ramaila, 2018; Hilton, 2018; Khan, 2020; Santos et al., 2019). This aligns with Participant A1's view that the absence of ICT resources deprives learners at School A of opportunities to learn. The participant emphasized that computers enhance the training of young minds in varied ways. This includes assisting them to do homework and other school projects; hence, its availability is a necessity and not a luxury. According to this participant, the absence of ICT resources has negative repercussions on learners' abilities to learn and perform.

The views of Participant A1 are re-echoed by Le Thi (2020), who contended that ICT resources enable learners to engage in individual research, hence enhancing self-study. Participant A2 corroborated the importance of ICT in teaching and learning, judging from its absence in School A. The participant noted that the lack of computers at the school has negative implications for learner development, considering that their ability to use the Internet for research was limited. In the participant's view, its availability has the potential to enhance learner motivation towards learning.

Furthermore, Padayachee (2017) argued that a lack of ICT resources can potentially hamper the kind of education learners receive, with implications for their performance. Based on research conducted in KwaZulu-Natal, Hodgson, and Khumalo (2016) argued that the availability of computers positively influences the way learners learn. Additionally, Hilton (2018) analyzed the importance of computers in the classroom and concluded in corroboration with Pohjolainen, Nykänen, Venho, and Kangas (2018) that ICT in the classroom has positive effects on learners' learning. Computers assist learners' research assignments and school projects and can potentially change the way they see and learn critical subjects like Mathematics (see Hegedus \& Moreno-Armella, 2020). This is pertinent because Mathematics learning is one of the problem areas in many South African primary schools (Bezuidenhout, Henning, Fitzpatrick, \& Ragpot, 2019; Rabana \& Martin, 2017), a phenomenon considered by Juta and Van Wyk (2020) as multifaceted. 
Participant A1, however, clarified that the DBE had provided the school with computers, but due to theft, these were no longer available. This resulted in learners thus being deprived of opportunities to use the computers in their learning endeavors (see Mbuza, 2019, 2020; Mdlongwa, 2012; Pijoos, 2020; Ramorola, 2018; Sedibe, 2011). In reality, the learners were deprived of the opportunity to explore and enjoy the benefits computers introduce into a learning environment. These narratives reiterate how contextual challenges prevent learners from accessing ICT resources and, ultimately, frustrating educators' zeal to assist learners to achieve the kind of education they desire (see Aziz, 2020; Bingimlas, 2009).

Besides, Participant A2 compared resourced and under-resourced schools in the province in terms of teaching using ICT tools. The participant's point of departure was that access to the Internet gives learners at resourced schools an edge over those in under-resourced schools. In the view of this participant, the lack of ICT resources in the under-resourced schools exacerbates existing challenges contributing to learners' poor performance when compared to those in resourced schools. According to this participant, the availability of computers can potentially increase learners' passion for learning. In corroboration, Participant B1 opined that the lack of computer laboratories is an acute problem in township schools, which are known for their disadvantageousness. Participant BI emphasized that these circumstances make it difficult for learners in these localities to conveniently use Internet facilities to research material for examinations, projects, and homework, with negative implications on their performance.

The discourses of Participants A2 and B1 indicate that ICT has the potential to motivate learners to learn and change their perceptions of education as a whole - an advantage seldom embraced by many learners in under-resourced schools. When ICT resources are available and integrated effectively in teaching in the classroom, learning becomes enjoyable, as learners become motivated, interested and more attached to what they do (see Hilton, 2018; Hines \& Lynch, 2019) and, in some cases, more responsible in the way they learn (see Hardman, 2019).

The positive attitudes of both educators and learners towards the impact of ICT resources in teaching and learning make it apt to argue that having a computer laboratory that continuously functions has the potential to increase learner educational aspirations, motivation and the desire to learn (see Denoon-Stevens \& Ramaila, 2018; Hilton, 2018; Santos et al., 2019). Unfortunately, the lack of ICT resources and other related factors cripples the zeal of using technology in the classroom in the selected schools. Similarly, Comi, Argentin, Gui, Origo, and Pagani (2017) noted that the level of learner motivation and a potentially positive change in perceptions towards learning depends on teachers' ability to integrate ICT in classroom spaces. Such effectiveness, in the view of Steiner and Mendelovitch (2017, p. 1259), occurs when educators use ICT resources to promote higher-order thinking through the usage of the necessary applications appropriate for teaching specific subjects, such as Science. For Hegedus and Moreno-Armella (2020), the introduction of new software and hardware 
technologies presents an added advantage in teaching and learning in specific subjects, including Mathematics. This reiterates the important role ICT plays in a teaching and learning environment.

4.2 The impact the lack of ICT resources has on teaching and learning. Participants were outspoken that the existing challenges at their schools impeded the usage of technology in the classroom, with negative repercussions for learners. The participants argued that such challenges hamper learners' aspirations to learn and their desire to become what they value in life. Hodgson and Khumalo (2016), in corroboration with Le Thi (2020), contended that, apart from doing assignments, learners with access to ICT resources are opportune to do research that will familiarize them with their future careers. Participants identified theft, insufficient funds to purchase data or repair broken computers, and inadequate technical and administrative support as those factors inhibiting ICT usage, thus negatively affecting the carrying out of teaching and learning.

Participant A1 unequivocally pointed out that theft was the major reason why their school had no computer laboratory, despite the DBE having provided them with such as required by policy. As such, learners were deprived of these resources in the classroom, not due to the Department's inability to provide them, but due to theft. However, participants were also quick to shift the blame onto the Department. This is because, unfortunately, the DBE expected each school to pay for its security, an expectation rather burdensome for schools in socioeconomically disadvantaged communities. Participant A1 noted that for multiple reasons, schools in disadvantaged communities, such as School A, are unlikely to meet the expectations of the DBE because challenges such as porous security expose their resources to thieves. This participant explained that 65 computers were stolen from their school. Since the school survived on a tight budget from the government, its ability to repair broken computers or to replace stolen ones was restricted, thus depriving learners of crucial educational opportunities.

Participant A1's argument indicates that the DBE's approach, requiring schools to pay for their security, was practically unfair and unrealistic considering that they operate with limited funds and are located in high-risk areas with frequent break-ins. In the participant's view, the consequences were felt more by the learners, who were deprived of the advantages that ICT resources introduce into the classroom. Several other reports exist across the country concerning computer theft, highlighting that, in certain South African contexts, schools with ICT resources face ongoing security challenges, with negative implications for ICT integration (see African News Agency, 2019; Mbuza, 2019, 2020; Mdlongwa, 2012; Ngqakamba, 2020; Sedibe, 2011). This challenge is, however, not limited to South Africa. Researchers such as Hussein, Abayo, and Mugambi (2019) and Mutisya and Mwania (2017), from a Kenyan perspective, established a link between insecurity and ICT integration, impacting negatively on teaching and learning. Consequently, Ramorola (2017) emphasized the importance of providing physical protection to schools with computer facilities, a suggestive move that can assist the government in achieving its goal of quality education for all. 
It is interesting to note, though, that because many socioeconomically disadvantaged areas in South Africa are notorious for criminal behavior (see Bhorat, Lilenstein, Monnakgotla, \& Thornton, 2017), insurance companies are unwilling to insure the property of schools located in such areas. In this regard, Participant A1 stated that insurance companies were unwilling to partner with their school because they are located in a high-risk area, making it impossible for them to receive any compensation when robbed of ICT resources.

This account indicates the extent to which criminal activities deprive learners of the quality education for all anticipated by the DBE's policies, including the ICT-integration project. Based on existing reports that relate to computer theft, participants were of the view that the DBE should consider the physical circumstances of individual schools and, in some contexts, provide security for schools with computers. Recent vandalization and theft of computer equipment across the country depict how many South African learners are deprived of opportunities to use ICT in the classroom (Maromo, 2020; Mbuza, 2020; Richardson, 2020). This observation is relevant because, in some situations, the Department has replaced stolen computers, but security challenges have prevented such schools from putting these new computers to good use, for fear of a repeat of theft and vandalism. A case in point is a school that experienced 12 burglaries in four years (Ground Up, 2017). Although the DBE had replaced the school's stolen computers in 2015, by 2017 they were not in use yet due to security concerns (Ground Up, 2017). This case reiterates the impact a lack of security has on ICT resources and the implications it has on teaching and learning (see Karunaratne et al., 2018). The prevailing circumstances at the school restrict their use of ICT resources for teaching and learning, despite these resources being available.

When referring to the physical circumstances of schools and security issues, participants were outspoken that the DBE should play a major role in assisting schools to repair broken computers or provide special budgetary allocations for the schools to do repairs themselves. In their view, this could assist in ensuring that the available ICT resources are put to good use in the classroom for the benefit of the learners. Participants also thought that it could be viable if the DBE assisted schools in the process of securing reliable insurance companies for school property, especially for ICT facilities. The participants contended that the greater the risk faced because of ICT resources, the higher the probability of depriving affected learners of the opportunity to benefit from the ICT-rollout plan of the DBE. Similarly, Hodgson and Khumalo (2016) argued that when learners lack access to ICT resources, they are deprived of enjoying the benefits that technology introduces in the classroom. This view is worth noting because the impact of the lack of ICT resources explored in this study is not unique to the schools concerned, but seemingly an ongoing South African problem. The nonutilization of ICT resources in the classroom has negative implications for learners' educational aspirations. There have been several reports over the years indicating the vulnerability of ICT resources in South African schools (see African News Agency, 2019; Ground Up, 2017; Maromo, 2020; Mbuza, 2019; Mdlongwa, 2012; News24, 2019; Sedibe, 2011). This reiterates the argument that 
the impact that the lack of ICT resources has on teaching and learning may continue to linger for much longer unless the impending challenges, including that of security, are tackled holistically. This claim is based on the nationwide vandalization and theft of ICT resources in schools across South Africa exacerbated by the national lockdown imposed due to COVID-19 (Maromo, 2020; Mbuza, 2020; Ngqakamba, 2020). This is not to say, however, that the Department is unaware of the problem or not finding ways to resolve it (see Parliamentary Monitoring Group, 2019).

However, theft and a lack of ICT resources are not the only challenges hindering the use of ICT resources in the classroom. For example, a computer laboratory was available at School $\mathrm{C}$ at the time of this research, but the computers were not in working order. As such, educators were unable to use them to assist learners in their learning endeavors. Participant $\mathrm{C} 1$ related that these computers broke down frequently and could not be repaired quickly, thereby restricting learners from engaging in online research (see Le Thi, 2020; Papaioannou \& Charalambous, 2011; Wilson-Strydom et al., 2005). In a practical sense, even though ICT resources were available in the school's computer laboratory, they were not meeting the educational needs of the learners, because the school lacked funds to purchase data and repair the broken computers. This aligns with Hodgson's (2012) view that, out of approximately 20 computers available at a poor school in the outskirts of Durban, none was in working condition, a situation that caused frustration for the computer teacher.

A further complication in some contexts is that, if schools are mandated to purchase data and/or do repairs themselves, it is unlikely for the ICT resources to be used regularly in teaching and learning spaces (see Karunaratne et al., 2018; Opoku, Badu, \& Alupo, 2016). Due to budgetary limitations, School C resorted to the option of using unskilled technicians to do repairs - thereby aggravating the frequency of computer breakdowns and further restricting learners from having regular access to the technology. According to Participant C2, complaints that emanated from School C in terms of ICT resources were mainly related to learners' inability to utilize the computer laboratory for months on end due to technical challenges. Efforts by school authorities to salvage the situation did not yield the expected results because the computer technicians recruited to repair the broken computers failed to deliver, thus depriving learners of opportunities to learn using technology.

The lack of technical, financial and administrative support for schools with ICT resources seems to be an ongoing challenge, with negative implications for teaching and learning (see Bingimlas, 2009; Johnson, Jacovina, Russell, \& Soto, 2016; Mirzajani et al., 2016; Papaioannou \& Charalambous, 2011; WilsonStrydom et al., 2005). This explains Ashiono's (2018, p. 248) report that when technical support is lacking, computers will not be maintained and the chances of ICT tools to fail during teaching and learning will thus be increased. Such occurrences obstruct learners from enjoying the benefits ICT tools introduce in the classroom. 


\section{Conclusion}

The paper explored the impact of the lack of ICT resources in classrooms in selected South African primary schools. The intention was to understand the impact the lack of ICT resources has on teaching and learning. The findings indicate the relevance of ICT resources in the classroom and the negative implications of the lack thereof. The lack of ICT resources frustrates the hopes and aspirations of learners and prevents them from enjoying the benefits associated with the introduction of ICT tools into the classroom. The prevailing circumstances in the selected schools indicate that the DBE needs to review its ICT-integration plans and policies concerning how it identifies and attends to challenges faced by individual schools across the country. We, therefore, recommend that the DBE should revamp its monitoring and evaluation mechanisms to identify and resolve challenges related to ICT availability and usage in individual school contexts timeously. Our perception is that such an approach will contribute to ensuring that existing resources do not remain unused or underutilized, or become stolen due to security concerns. Such occurrences would mean a major setback in the DBE's endeavors to ensure that all children receive a quality education, in an era where technology is increasingly becoming a teaching and learning mode of choice. Since the DBE may not have enough capability to assist all schools across the country in all dimensions, we also recommend that schools collaborate, through partnerships with communities, to ensure safer schools. The nationwide vandalism and theft of ICT equipment in schools during the lockdown caused by COVID-19 are due to porous security in schools with technological resources, thus validating the need for measures such as those suggested. More research on ICT-related challenges around the country is needed to provide a holistic picture of the problem to provide more data for government action going forward.

\section{References}

African News Agency. (2019, January 16). ANC irked by theft of computers from new state-of-the-art primary school. IOL. Retrieved from https://www.iol.co.za/news/politics/anc-irked-by-theft-of-computers-fromnew-state-of-the-art-primary-school-18833497

Aluwihare-Samaranayake, D. (2012). Ethics in qualitative research: A view of the participants' and researchers' world from a critical standpoint. International Journal of Qualitative Methods, 11(2), 64-81. https://doi.org/10.1177/160940691201100208

Arrieta, G. S. (2020). Assessment of the ICT integration in teaching Math and Science in high school: Basis for an ICT integration program. Jurnal Pendidikan MIPA, 21(1), 95-108. https://dx.doi.org/10.23960/jpmipa/v21i1.pp95-108

Ashiono, B. L. (2018). Supporting teachers in their use of ICT in teaching Mathematics: What kind of support is necessary and when is it required? Matters of Behaviour, 6(7), 1-8. https://doi.org/10.26455/mob.v6i7.35

Aziz, A. (2020). Digital inclusion challenges in Bangladesh: The case of the National ICT Policy. Contemporary South Asia, 1-16. https://doi.org/10.1080/09584935.2020.1793912

Bezuidenhout, H., Henning, E., Fitzpatrick, C., \& Ragpot, L. (2019). Early Mathematics vocabulary and number concept development. In book of proceedings, South African Association for Research in Mathematics, Science and Technology (SAARMSTE), 
pp. 2-15, January 15-17, University of KwaZulu-Natal, Durban, South Africa. Retrieved from

https://saarmste.org/images/Conference_Proceedings/SAARMSTE2019-

University_of_KwaZulu-Natal/SAARMSTE_2019_-

_Book_of_Proceedings.pdf\#page $=15$

Bhorat, H., Lilenstein, A., Monnakgotla, J., \& Thornton, A. (2017). The socio-economic determinants of crime in South Africa: An empirical assessment. Working Paper 201704. Development Policy Research Unit, University of Cape Town. Retrieved from https:/ / www.africaportal.org/publications/socio-economic-determinantscrime-south-africa-empirical-assessment/

Bingimlas, K. A. (2009). Barriers to the successful integration of ICT in teaching and learning environments: A review of the literature. Eurasia Journal of Mathematics, Science \& Technology Education, 5(3), 235-245. https:// doi.org/10.12973/ejmste/75275

Chisango, G., \& Lesame, C. (2017). Challenges of information and communication technology policy implementation in rural South Africa. Communitas, 22, 48-61. https://doi.org/10.18820/24150525/Comm.v22.4

Comi, S. L., Argentin, G., Gui, M., Origo, F., \& Pagani, L. (2017). Is it the way they use it? Teachers, ICT, and student achievement. Economics of Education Review, 56, 24-39. https://doi.org/10.1016/j.econedurev.2016.11.007

Denoon-Stevens, S. P., \& Ramaila, E. (2018). Community facilities in previously disadvantaged areas of South Africa. Development Southern Africa, 35(4), 432-449. https:// doi.org/10.1080/0376835X.2018.1456906

Department of Basic Education (DBE). (2011). South African Schools Act, 1996 (Act No. 84 of 1996) Amended National Norms and Standards for School Funding (NNSSF). Government Gazette, No. 33973. Retrieved from https://www.gov.za/sites/default/files/gcis_document/201409/33973gon48.p df

Department of Basic Education (DBE). (2014). Implementation strategy for e-Education in South Africa 2013-2025. PowerPoint presentation. Retrieved from http://www.bridge.org.za/wp-content/uploads/2014/12/ICTs-

DBE\%E2\%80\%99s-New-E-Education-Strategy-Presentation-Nov-2012.pdf

Department of Education (DoE). (2003). White Paper on e-Education. Transforming learning and teaching through information and communication technologies. Department of Education. Retrieved from https://www.gov.za/sites/default/files/gcis_document/201409/eeducation1.pdf

Department of Education (DoE). (2004). Draft White Paper on e-Education: Transforming learning and teaching through information and communication technologies (ICTs). Government Gazette, Vol. 470, No. 26734. Retrieved from https://www.gov.za/sites/default/files/gcis_document/201409/267341.pdf

Flick, U. (2018). An introduction to qualitative research (6 $6^{\text {th }}$ ed.). London: Sage.

Garg, A., Shukla, B., \& Kendall, G. (2015). Barriers to implementation of IT in educational institutions. The International Journal of Information and Learning Technology, 32(2), 94-108. https:/ / doi.org/10.1108/IJILT-11-2014-0026

Genlott, A. A., \& Grönlund, А. (2016). Closing the gaps: Improving literacy and Mathematics by ICT-enhanced collaboration. Computers $\mathcal{E}$ Education, 99, 68-80. https:// doi.org/10.1016/j.compedu.2016.04.004

Ground Up. (2017, October 24). Thieves steal primary school children's education in Nyanga. The South African. Retrieved from 
https://www.thesouthafrican.com/news/school-children-denied-educationalhelp-due-to-thieves/

Habibi, A., Razak, R. A., Yusop, F. D., Mukminin, A., \& Yaqin, L. N. (2020). Factors affecting ICT integration during teaching practices: A multiple case study of three Indonesian universities. Qualitative Report, 25(5), 1127-1144. https://eds.b.ebscohost.com/eds/pdfviewer/pdfviewer?vid=1\&sid=59300fe24138-408c-8982-b179137cf9b3\%40sessionmgr103

Hardman, J. (2019). Towards a pedagogical model of teaching with ICTs for Mathematics attainment in primary school: A review of studies 2008-2018. Heliyon, 5(5), 1-6. https:// doi.org/10.1016/j.heliyon.2019.e01726

Hegedus, S., \& Moreno-Armella, L. (2020). Information and communication technology (ICT) affordances in Mathematics education. Encyclopedia of Mathematics Education, 380-384. https://doi.org/10.1007/978-3-030-15789-0_78

Hilton, A. (2018). Engaging primary school students in Mathematics: Can iPads make a difference? International Journal of Science and Mathematics Education, 16(1), 145-165. https://doi.org/10.1007/s10763-016-9771-5

Hines, M. G., \& Lynch, R. (2019). The relationship of Grade 7 students' general ICT use and attitudes towards ICT use for school-related activities with ICT self-efficacy in eleven English program schools of Thailand. Scholar: Human Sciences, 11(2), 366-384

Hodgson, H. (2012, September 22). Computer literacy out of reach. Mail \& Guardian. Retrieved from https://mg.co.za/article/2012-09-22-computer-literacy-out-ofreach/

Hodgson, T. F., \& Khumalo, S. (2016, August 14). Too many children left behind: Exclusion in the South African inclusive education system. With a focus on the Umkhanyakude district, KwaZulu-Natal (A SECTION27 Report). Retrieved from http://section27.org.za/wp-content/uploads/2016/08/UmkhanyakudeReport-Final-08082016-1.pdf

Hussein, Q., Abayo, R., \& Mugambi, H. (2019). Determinants of digital learning implementation in public primary schools: A case of Nairobi county schools. International Academic Journal of Human Resource and Business Administration, 3(6), $150-161$

Ismail, S. A. M. M., Jogezai, N. A., \& Baloch, F. A. (2020). Hindering and enabling factors towards ICT integration in schools: A developing country perspective. Elementary Education Online, 19(3), 1537-1547. http://dx.doi.org/10.17051/ilkonline.2020.733176

Jimenez, E. C. (2020). Motivating factors of teachers in developing supplementary learning materials (SLMs). Online Submission, 8(5), 108-113. http://dx.doi.org/10.21474/IJAR01/10912

Joffe, H. (2012). Thematic analysis. In D. Harper \& A. Thompson (Eds.), Qualitative methods in mental health and psychotherapy: A guide for students and practitioners (pp. 209-223). Chichester: Wiley.

Johnson, A. M., Jacovina, M. E., Russell, D. E., \& Soto, C. M. (2016). Challenges and solutions when using technologies in the classroom. In S. A. Crossley \& D. S. McNamara (Eds.), Adaptive educational technologies for literacy instruction (pp. 13-29). New York: Taylor \& Francis.

Juta, A., \& Van Wyk, C. (2020). Classroom management as a response to challenges in Mathematics education: Experiences from a province in South Africa. African Journal of Research in Mathematics, Science and Technology Education, 24(1), 21-30. https://doi.org/10.1080/18117295.2020.1731646 
Karunaratne, T., Peiris, C., \& Hansson, H. (2018). Implementing small scale ICT projects in developing countries: How challenging is it? International Journal of Education and Development using ICT, 14(1), 118-140. Retrieved from https://www.learntechlib.org/p/183556/

Khan, Z. N. (2020). Role of ICT on the academic achievement of Madrasa students. International Research in Education, 8(2), 23-32. https://doi.org/10.5296/ire.v8i2.17277

Kwet, M. (2017). Operation Phakisa education: Why a secret? Mass surveillance, inequality, and race in South Africa's emerging national e-Education system. First Monday, 22(12). https://doi.org/10.5210/fm.v22i12.8054

Le Thi, M. A. I. (2020). Benefits and challenges to integrate ICT in EFL teaching and learning activities. Journal of Research $\mathcal{E}$ Method in Education (IOSR-JRME), 10(3), 46-50. http://dx.doi.org/10.9790/7388-1003044650

Lim, C. P. (2002). A theoretical framework for the study of ICT in schools: A proposal. British Journal of Educational Technology, 33(4), 411-421. https://doi.org/10.1111/1467-8535.00278

Maromo, J. (2020, April 17). Almost 400 SA schools vandalized during the Covid-19 lockdown. African News Agency/ANA. Retrieved from https://www.iol.co.za/news/politics/almost-400-sa-schools-vandalisedduring-covid-19-lockdown-46832389

Mbuza, E. (2019, July 25). Stealing SA's future: 250 computers stolen from Gauteng schools in 2019. Times Live. Retrieved from https://www.timeslive.co.za/news/south-africa/2019-07-25-stealing-sasfuture-250-computers-stolen-from-gauteng-schools-in-2019/

Mbuza, E. (2020, April 30). Nearly 1,000 schools vandalized since start of lockdown, food stolen. Times Live. Retrieved from https://www.timeslive.co.za/news/southafrica/2020-04-30-nearly-1000-schools-vandalised-since-start-of-lockdown-foodstolen/

Mdlongwa, T. (2012). Information and communication technology (ICT) as a means of enhancing education in schools in South Africa. Policy Brief: Africa Institute of South Africa. Retrieved from http://www.ai.org.za/wpcontent/uploads/downloads/2012/10/No.-80.-ICTas-a-means-of-enhancingEducation-in-Schools-in-South-Africa.pdf

Merriam, S. B. (2009). Qualitative research: A guide to design and implementation. San Francisco: Jossey-Bass.

Merriam, S. B., \& Grenier, R. S. (Eds.). (2019). Qualitative research in practice: Examples for discussion and analysis (2nd ed.). San Francisco: John Wiley \& Sons.

Mirzajani, H., Mahmud, R., Ayub, A. F. M., \& Wong, S. L. (2016). Teachers' acceptance of ICT and its integration in the classroom. Quality Assurance in Education, 24(1), 2640. https://doi.org/10.1108/QAE-06-2014-0025

Mjwara, P. (2017, June 2). Shaping the future of SA's economic growth through science, technology and innovation. Mail $\mathcal{E}$ Guardian. Retrieved from https:/ / mg.co.za/article/2017-06-02-00-shaping-the-future-of-sas-economicgrowth-through-science-technology-and-innovation

Mutisya, A. M., \& Mwania, J. M. (2017). The influence of community related factors on ICT integration in management of public secondary schools in Kitui County, Kenya. International Journal of Innovative Research and Advanced Studies, 4(12), 4348.

News24. (2019, January 8). SA's biggest challenges in 2019. News24. Retrieved from https://www.news24.com/MyNews24/sas-biggest-challenges-in-201920190108 
Ngqakamba, S. (2020, April 16). Gauteng school break-ins: More arrests as number of vandalised, robbed schools spikes to 67. News 24. Retrieved from https://www.news24.com/news24/southafrica/news/gauteng-school-breakins-more-arrests-as-number-of-vandalised-robbed-schools-spikes-to-67-20200416

Odendaal, N. (2017, January 20). Operation Phakisa making strides in ICT in education. Creamer Media. Retrieved from http://m.engineeringnews.co.za/article/operation-phakisa-making-strides-inict-in-education-2017-01-20

Opoku, M. P., Badu, E., \& Alupo, B. A. (2016). Effort at implementing ICT policy in basic schools in Ghana: An assessment of available facilities and resources for successful ICT education within the Atwima Nwabiagya district in Ashanti region. Sosiohumanika: Jurnal Pendidikan Sains Sosial dan Kemanusiaan, 9(1), 183-194. Retrieved from http://www.journals.mindamas.com/index.php/sosiohumanika/article/view $/ 665$

Padayachee, K. (2017). A snapshot survey of ICT integration in South African schools. South African Computer Journal, 29(2), 36-65. http://dx.doi.org/10.18489/sacj.v29i2.463

Papaioannou, P., \& Charalambous, K. (2011). Principals' attitudes towards ICT and their perceptions about the factors that facilitate or inhibit ICT integration in primary schools of Cyprus. Journal of Information Technology Education: Research, 10(1), 349-369. https:// doi.org/10.28945/1530

Parliamentary Monitoring Group. (2019, September 10). Safety \& Security in schools: Briefing by DBE and SAPS, with Minister of Basic Education. Retrieved from https:// pmg.org.za/committee-meeting/28835/

Parliament of the Republic of South Africa. (2018). Analysis of basic education report on the ICT rollout. Research Unit, Cape Town. Retrieved from http://pmg-assets.s3website-eu-west-1.amazonaws.com/180227analysis.pdf

Patton, M. Q. (2005). Qualitative research. Hoboken, NJ: John Wiley.

Pholotho, T., \& Mtsweni, J. (2016) Barriers to electronic access and delivery of educational information in resource constrained public schools: A case of Greater Tubatse Municipality. Proceedings of Institute of Electrical and Electronics Engineers, IST-Africa, pp. 1-9, May 11-13, Durban, South Africa. https://doi.org/10.1109/istafrica.2016.7530626

Pijoos, I. (2020, May 22). Tip-off leads to arrests for 'theft of school computers'. Times Live. Retrieved from https://www.timeslive.co.za/news/south-africa/2020-0522-tip-off-leads-to-arrests-for-theft-of-school-computers/

Pohjolainen, S., Nykänen, O., Venho, J., \& Kangas, J. (2018). Analysing and improving students' mathematics skills using ICT-tools. Eurasia Journal of Mathematics, Science and Technology Education, 14(4), 1221-1227. https://doi.org/10.29333/ejmste/81869

Rabah, J. (2015). Benefits and challenges of information and communication technologies (ICT) integration in Québec English schools. Turkish Online Journal of Educational Technology, 14(2), 24-31. Retrieved from https:// files.eric.ed.gov/fulltext/EJ1057526.pdf

Rabana, R., \& Martin, J. (2017, July 21). Integrating technology beyond paperless classrooms. Mail \& Guardian. Retrieved from https://mg.co.za/article/2017-0721-00-integrating-technology-beyond-paperless-classrooms

Ramorola, M. Z. (2017). Strategies for successful technology integration in teaching and learning. Proceedings of the South Africa International Conference on Education, pp. 195-206, September 18-20, Pretoria, South Africa. 
Ramorola, M. Z. (2018). Transforming teaching and learning through technology integration. Inaugural Lecture, May 3, University of South Africa, South Africa. Retrieved from

http://uir.unisa.ac.za/bitstream/handle/10500/24118/TECHNOLOGY\%20INT EGRATION\%20IN\%20TEACHING\%20AND\%20LEARNING_FINAL\%2827\%29. pdf? sequence $=1 \&$ isAllowed $=y$

Richardson, J. (2020, April 30). Motshekga concerned about theft and vandalism at schools. The South African. Retrieved from https://www.thesouthafrican.com/news/motshekga-theft-vandalism-atschools/

Santos, G. M., Ramos, E. M., Escola, J., \& Reis, M. J. (2019). ICT literacy and school performance. Turkish Online Journal of Educational Technology, 18(2), 19-39. Retrieved from https://eric.ed.gov/?id=EJ1211197

Sedibe, M. (2011). Inequality of access to resources in previously disadvantaged South African high schools. Journal of Social Sciences, 28(2), 129-135. https://doi.org/10.1080/09718923.2011.11892937

Steiner, D., \& Mendelovitch, M. (2017). "I'm the same teacher": The attitudes of Science and Computer Literacy teachers regarding integrating ICT in instruction to advance meaningful learning. EURASIA Journal of Mathematics, Science and Technology Education, 13(5), 1259-1282. https://doi.org/10.12973/eurasia.2017.00670a

Terry, G., Hayfield, N. Clarke, V., \& Braun, V. (2017). Thematic analysis. In C. Willis \& W. Stainton-Rogers (Eds.), The SAGE handbook of qualitative research in psychology ( $2^{\text {nd }}$ ed., pp. 17-36). London: Sage. https://dx.doi.org/10.4135/9781526405555

Williams, M., \& Moser, T. (2019). The art of coding and thematic exploration in qualitative research. International Management Review, 15(1), 45-55. Retrieved from

https://pdfs.semanticscholar.org/5dd2/51ddfbb6a563b900e53a9b3476a8c4b255 7b.pdf

Wilson-Strydom, M., Thomson, J., \& Hodgkinson-Williams, C. (2005). Understanding ICT integration in South African classrooms: Research information and communication technologies. Perspectives in Education, 23(1), 71-85. Retrieved from https:/ /hdl.handle.net/10520/EJC87344

Yang, D., \& Baldwin, S. J. (2020). Using technology to support student learning in an integrated STEM learning environment. International Journal of Technology in Education and Science, 4(1), 1-11. Retrieved from https://eric.ed.gov/?id=EJ1230543

Yin, R. K. (2018). Case study research and applications: Design and methods (6 $6^{\text {th }}$ ed.). Los Angeles, CA: Sage.

Yuen, A. H., Law, N., \& Wong, K. C. (2003). ICT implementation and school leadership: Case studies of ICT integration in teaching and learning. Journal of Educational Administration, 41(2), 158-170. https:/ / doi.org/10.1108/09578230310464666

Zakaria, N. A., \& Khalid, F. (2016). The benefits and constraints of the use of information and communication technology (ICT) in teaching Mathematics. Creative Education, 7(11), 1537-1544. https://doi.org/10.4236/ce.2016.711158 